\title{
Sistem Penyiraman Tanaman Otomatis Berbasis Sensor Kelembaban Tanah Menggunakan Logika Fuzzy
}

\author{
Satria Bimo Mursalin ${ }^{1}$, Hastha Sunardi ${ }^{2}$, Zulkifli $^{3)}$ \\ ${ }^{1223)}$ Program Studi Sistem Komputer, Universitas Indo Global Mandiri \\ Jalan Jend. Sudirman No. 629 KM. 4 Palembang Kode pos 30129 \\ Email:2015310009@students.uigm.ac.id ${ }^{1}$, hastha_s@uigm.ac.id ${ }^{2}$, zulkifli@uigm.ac.id $\left.{ }^{3}\right)$
}

\begin{abstract}
Watering plants is important so that plants can grow in a fertile and optimal way. therefore an automatic plant watering can be made. This tool aims to replace the manual work becomes automatic. The benefit of this tool is that it can simplify human work in watering plants automatically. The making of this final project aims to apply fuzzy logic in watering plant automation based on soil moisture. With this tool, it is expected to be able to help plant maintenance processes better. Fuzzy logic is one method that can be used in control systems in order to provide decisions that resemble human decisions because they have concepts that are easy to understand and are based on natural language. The making of this final project is done by designing, making and implementing system components which include Arduino uno as a controller, Water pump, LCD (liquid Cristal Display) to display soil moisture values. the results of the research prove that the tools made can function well and can be developed as expected.
\end{abstract}

Keyword : Soil Moisture, Watering Plants, Fuzzy Logic, Arduino Uno

\begin{abstract}
Abstrak
Penyiraman tanaman merupakan hal yang penting agar tanaman dapat tumbuh dengan subur dan optimal.maka dari itu dibuatlah alat penyiram tanaman otomatis. Alat ini bertujuan untuk menggantikan pekerjaan manual menjadi otomatis.Manfaat yang didapat dari alat ini adalah dapat mempermudah pekerjaan manusia dalam menyiram tanaman secara otomatis.Pembuatan tugas akhir ini bertujuan untuk menerapkan logika fuzzy pada otomatisasi penyiraman tanaman berdasarkan kelembaban tanah. Dengan adanya alat ini diharapkan dapat membantu proses perawatan tanaman dengan lebih baik. Logika fuzzy merupakan salah satu metode yang dapat digunakan pada sistem kendali agar dapat memberikan keputusan yang menyerupai keputusan manusia karena memiliki konsep yang mudah dimengerti dan didasarkan pada bahasa alami. Pembuatan tugas akhir ini dilakukan dengan merancang, membuat dan mengimplementasikan komponen-komponen sistem yang meliputi Arduino uno sebagai pengendali, pompa Air, LCD (liquid Cristal Display) untuk menampilkan nilai kelembaban tanah. hasil penelitian membuktikan alat yang dibuat dapat berfungsi dengan baik dan dapat dikembangkan sesuai yang diharapkan.
\end{abstract}

Kata kunci : Kelembaban Tanah, Penyiraman Tanaman, Logika Fuzzy, Arduino Uno 


\section{Pendahuluan}

Penyiraman tanaman merupakan suatu kegiatan yang perlu diperhatikan dalam melakukan pemeliharaan tanaman, dikarenakan tanaman memerlukan asupan air yang cukup untuk melakukan fotosintesis dalam memperoleh kebutuhannya untuk tumbuh dan berkembang. salah satu faktor yang mempengaruhi pada perkembangan tanaman yaitu penyiraman. Kebutuhan air yang cukup merupakan salah satu hal yang sangat penting. Jika hal ini tidak diperhatikan maka akan berdampak fatal bagi perkembangan tanaman itu sendiri. Namun cara ini kurang efektif, karena membutuhkan banyak waktu dan tenaga. Pemilik juga tidak bisa meninggalkan tanaman dalam kurun waktu yang lama, karena tanaman dapat kekurangan air dan menyebabkan kematian. Kelembaban tanah merupakan salah satu parameter penting untuk proses hidrologi, biologi dan biogeokimia ( Sintia, 2008 ).

Penelitian yang berkaitan dengan pembuatan alat penyiraman tanaman otomatis sudah banyak dilakukan, salah satunya adalah penelitian yang dilakukan oleh(Pranata, Irawan and Ilhamsyah, 2015) telah melakukan penelitian mengenai sistem penyiraman tanaman otomatis dengan menerapkan logika fuzzy. Pada penelitian ini dilakukan pengujian sistem pada tanaman seledri yang mana masi terdapat nilai kesalahan ini dapat disebabkan oleh beberapa hal seperti, perhitungan dalam penentuan waktu penyiraman yang belum terlalu akurat, variabel keluaran untuk sistem fuzzy hanya lima buah, dan tingkat akurasi dari pembacaan sensor kelembaban tanah.(Kurniawan, 2015) telah melakukan penelitian Alat Penyiraman tanaman otomatis dengan logika fuzzy berbasis ATMEGA16.Pada sistem ini menggunakan sensor LM35 dan sensor SEN0057 sebagai input dari sistem penyiraman dan menggunakan metode fuzzy dalam menentukan sistem akan bekerja. Hasil dari penelitian tersebut pengujian sensor LM35 output tegangannya sesuai dengan dasar teori yang ada di mana outputnya adalah $10 \mathrm{mV} / \mathrm{C}$. Dalam pengambilan nilai output menggunakan fuzzy inferen sistem masih terdapat rata-rata error sebesar $2,34 \%$.

\section{A. Perumusan Masalah}

Berdasarkan uraian pada latar belakang, maka yang menjadi perumusan masalah adalah bagaimana membuat sistem yang dapat melakukan penyiraman secara otomatis berdasarkan kelembaban tanah.

\section{B. Batasan Masalah}

Mengingat akan luasnya permasalahan yang terkait penelitian ini, penulis hanya akan membahas tentang:

1. Pengukuran kelembaban tanah atau tanah yang diukur kelembabannya memiliki Ph bersifat basa / asam rentangPh $0-45 \%$.

2. Jenis tanah yang digunakan adalah tanah bakaran hasil sisa pempakaran.

3. Luas pot tanaman yang dipakai dalam pengujian alat ini berukuran diameter $30 \mathrm{~cm}$
4. Pembacaan sensor kelembaban tanah hanya membaca dari Ph 0 - $45 \%$

5. Penyiraman tanaman hanya dilakukan rentang waktu 1 hari sekali.

\section{Tujuan}

Tujuan penelitian ini yaitu :

1. Membuatsistem penyiraman tanaman secara otomatis untuk menjaga kelembaban tanah.

2. Mengaplikasikan mikrokontroler arduino uno dengan sensorkelembaban tanah untuk menyiram tanaman secara otomatis.

\section{Manfaat}

Manfaat yang diharapkan dari penelitian ini yaitu :

1. Memudahkan manusia dalam memelihara tanaman.

2. Tanaman dapat tumbuh subur dan terjaga kelembaban tanahnya.

3. Penyiraman tanaman dapat dengan mudah terpantau oleh pemilik tanaman.

\section{E. Landasan Teori}

Bagian ini memuat data teori yang diperlukan dan digunakan dalam pembuatan alat penyiraman otomatis.

1. Pengenalan Tanah

Tanah sangat vital peranannya bagi semua kehidupan di bumi karena tanah mendukung kehidupan tumbuhan dengan menyediakan hara dan air sekaligus sebagai penopang akar.Struktur tanah yang berongga-rongga juga menjadi tempat yang baik bagi akar untuk bernapas dan tumbuhan.Tanah juga menjadi habitat hidup berbagai mikroorganisme.Bagi sebagian hewan darat, tanah menjadi lahan untuk hidup dan bergerak.Ilmu yang mempelajari berbagai aspek mengenai tanah dikenal sebagai ilmu tanah.Dari segi klimatologi, tanah memegang peranan penting sebagai penyimpan air dan menekan erosi, meskipun tanah sendiri juga dapat erosi. Proses pembetukan tanah dikenal sebagai "pedogenesis". Proses yang unik ini membentuk tanah sebagai tubuh alam yang terdiri atas lapisan - lapisan atau disebut sebagai horizon tanah. Setiap horizon menceritakan mengenai asal dan proses-proses fisika, kimia, dan biologi yang telah dilalui tubuh tanah tersebut (Naibaho \& Batara, 2017).

2. Sensor Kelembaban Tanah

Dalam penelitian menggunakan sensor kelembaban tanah dengan memanfaatkan rangkaian pembagi tegangan. Dengan cara mengukur resistansi tanah maka dapat diketahui nilai kelembaban tanah tersebut. Teknologi microchip elektronika.Penemuan ini menyebabkan perangkat komputer yang tadinya besar sudah berkembang sejak ditemukan bahan semikonduktor sebagai komponen menjadi kecil.Semikonduktor sebagai bahan pembuatan IC (Integrated Circuit) yang menjadikan teknologi microchip dan microcomputer semakin maju pesat. Pada penelitian ini peneliti menggunakan microchip atau microcontroller Arduino yang sudah didesain khusus untuk memudahkan para perancang prototype melakukan uji coba dalam membangun suatu alat dalam 
hal ini alat penyiram tanaman otomatis. Sensor yang digunakan dalam penelitian ini adalah sensor plat logam yang bersifat resistif untuk mengukur kelembaban tanah yang dikonversi menjadi tegangan analog yang kemudian akan dibaca oleh microcontroller yang telah diisi dengan program (embedded system). Sehingga alat akan bekerja sesuai dengan hasil penelitian yang akan dilakukan (Gunawan \& Sari, 2018).

3. L298N

Driver motor L298N biasa digunakan untuk mengendalikan motor agar motor dapat dikendalikan melalui mikrokontroler, sehingga motor dapat berputar dan kecepatan motor bisa diatur termasuk arah putar. Driver Motor L298N berfungsi sebagai penguat arus dan tegangan, sehingga motor mendapatkan supply arus yang sesuai. Driver L298N adalah driver motor DC, H-Bridge yang paling sederhana dan mudah untuk dipergunakan, untuk rangkaian pun menjadi lebih simple dan sederhana (Detector, 2017)

\section{Arduino}

Arduino Uno R3 adalah board berbasis mikrokontroler, pada arduino terdapat ATmega328 yang memiliki memiliki 14 digital input / output pin (dimana 6 pin dapat digunakan sebagai output PWM), 6 input analog, $16 \mathrm{MHz}$ osilator kristal, koneksi USB, jack listrik tombol reset. Pin-pin ini berisi semua yang diperlukan untuk mendukung mikrokontroler, hanya terhubung ke komputer dengan kabel USB atau sumber tegangan bisa didapat dari adaptor AC-DC atau baterai untuk menggunakannya (Aryanto et al., 2015).

Untuk menghubungkan arduino dengan komputer atau menanamkan program pada mikro tersebut dibutuhkan software. Software arduino yaitu berupa software processing yang digunakan untuk menulis program kedalam Arduino Uno. Software Arduino dapat di-install di berbagai operating sistem seperti Linux, Mac OS, Windows. Software IDE (Integrated DevelopmentEnvironment) Arduino Uno terdiri dari tiga bagian yaitu (Mulyana \& Kharisman, 2014).

5. Pompa Air

Pompa Air adalah suatu alat atau mesin yang digunakan untuk memindahkan cairan dari suatu tempat ke tempat yang lain melalui suatu media perpipaan dengan cara menambahkan energi pada cairan yang dipindahkan dan berlangsung secara terus menerus. Pompa beroperasi dengan prinsip membuat perbedaan tekanan antara bagian masuk (suction) dengan bagian keluar (discharge). Dengan kata lain, pompa berfungsi mengubah tenaga mekanis dari suatusumber tenaga (penggerak) menjadi tenaga kinetis (kecepatan), dimana tenaga ini berguna untuk mengalirkan cairan dan mengatasi hambatan yang ada sepanjang pengaliran(Pid, Informatika, Teknik, \& Oleo, 2016).

6. LCD (Liquid Crystal Display) 16x2

Display LCD adalah penampil kristal cair yang terdiri atas tumpukan sel dari dua lembar kaca yang sampingnya tertutup rapat. Antar dua kaca tersebut diberi bahan elektroda transparan indium oksida dalam bentuk tampilan seven- segment dan lapisan elektroda pada kaca belakang. Pada saat elektroda diaktifkan dengan medan listrik (tegangan), molekul organik yang panjang dan silindris menyesuaikan diri dengan elektroda dari segmen. Lapisan sandwich memiliki polarizer cahaya vertikal depan dan polarizer cahaya horizontal belakang yang diikuti dengan lapisan reflektor. Cahaya yang dipantulkan tidak dapat melewati molekul-molekul yang telah menyesuaikan diri dan segmen yang diaktifkan terlihat menjadi gelap dan membentuk karakter data yang ingin ditampilkan.(Palupi, 2018).

\section{LM2596}

Rangkaian terpadu monolitik yang ideal untuk desain pengatur switching step-down yang mudah dan nyaman (buck converter). Ini mampu menggerakkan beban 3,0 A dengan sangat baik line dan peraturan beban. Perangkat ini tersedia dalam output yang dapat diatur versi dan kompensasi internal untuk meminimalkan jumlah komponen eksternal untuk menyederhanakan desain suatu catu daya. Karena konverter LM2596 adalah power supply switch-mode, yaitu efisiensi secara signifikan lebih tinggi dibandingkan dengan yang populer regulator linier tiga terminal, terutama dengan voltase masukan yang lebih tinggi. LM2596 beroperasi pada frekuensi switching $150 \mathrm{kHz}$ memungkinkan komponen filter berukuran lebih kecil dari yang dibutuhkan dengan regulator pengalih frekuensi rendah. Tersedia dalam standar Paket TO-220 5-lead dengan beberapa pilihan tikungan yang berbeda, dan D2PAK mount permukaan paket(Tullah, Setyawan, \& Tanah, 2019).

\section{Logika Fuzzy}

Fuzzy Logic pertama kali diperkenalkan oleh Prof. Lotfi Zadeh seorang kebangsaan Iran yang menjadi guru besar di Universityof California at Berkeley pada tahun 1965.Fuzzy Logic adalah cabang dari sistem kecerdasan buatan (ArtificialIntelegent) yang mengemulasi kemampuan manusia dalam berfikir ke dalam bentuk algoritma yang kemudian dijalankan oleh mesin (Palupi, 2018).

Logika fuzzy merupakan metode yang bisa digunakan sebagai proses pengambilan keputusan berdasarkan aturan (rule) untuk memecahkan masalah non-linear menggunakan persamaan logika dari identifikasi kasus. Metode ini biasanya merepresentasikan hal-hal di dunia nyata menggunakan variabel linguistiknya dan nilai keangotaan antara 0 hingga 1 . Sistem logika fuzzy terdiri dari himpunan fuzzy (set), aturan fuzzy (rule) dan bilangan fuzzy(Masturi et al., 2017).

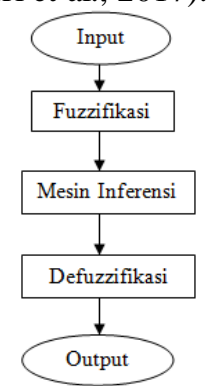

Gambar 1. Flowchart logika fuzzy (Parewe \& mahmudy, 2016) 


\section{Logika Fuzzy Sugeno}

Takana, Sugeno, dan Kang yang memperkenalkan metode sistem inferensi fuzzy Sugeno dan biasanya sering disebut juga metode sistem Inferensi fuzzy TSK. Output dari sistem inferensi fuzzy diperlukan 4 tahap (Haryanto \& Nasari, 2015).

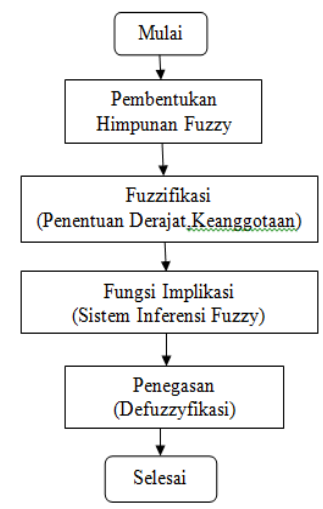

Gambar 2. Flowchart Metode Sugeno (Mahmud, 2016)

\section{F. Metodelogi Penelitian}

Pada penelitian ini menjelaskan bagaimana tahaptahap yang akan dilakukan dalam penelitian ini. Adapun gambaran dalam kerangka kerja dapat dilihat pada gambar 3 .

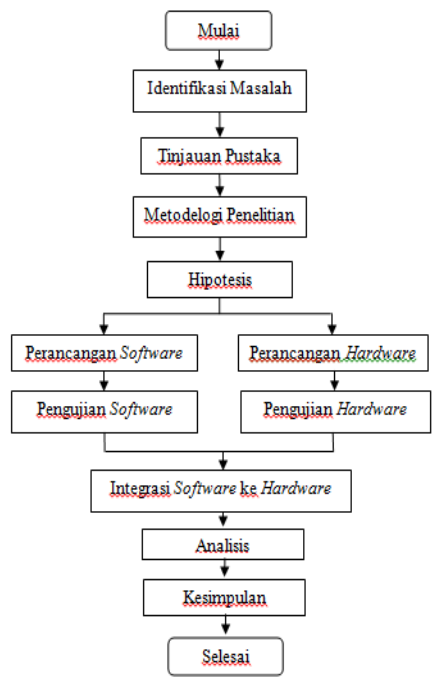

Gambar 3. Kerangka Kerja (Framework)

1. Perancangan Perangkat keras (Hardware)

Pada penelitian ini terlebih dulu melakukan perancangan blok diagram dari keseluruhan sistem yang akan dibangun seperti ditunjukan pada gambar 4.

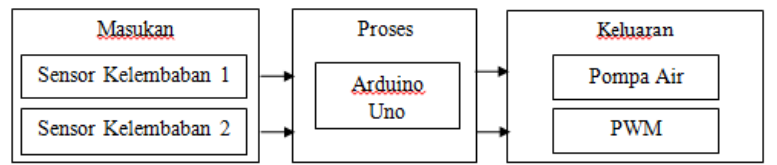

Gambar 4. Diagram Blok Sistem

Berikut adalah penjelasan dari blok diagram Sistem pada gambar 4 . a. Sensor kelembaban tanah / Moisture Probe adalah suatu alat yang terbuat dari materi logam dengan bahan tertentu. Prinsip kerja penggunaan sensor ini untuk pengukuran kelembaban tanah adalah sebagai berikut, moisture probe dimasukkan dalam tanah yang akan diukur kelembabannya dan dihubungkan dengan generator sinyal. Bila kadar air (kelembaban) tanah berubah, maka probeakan menghasilkan perubahan nilai kapasitansi, akibat permitivitas dielektriknya berubah. Perubahan nilai kapasitansi (impedansi) ini akan mengubah besarnya frekuensi gelombang keluaran generator sinyal. Dengan demikian, frekuensi gelombang keluaran generator sinyal akan berubah sesuai dengan kelembaban tanah. Perubahan frekuensi yang terjadi ini selanjutnya akan diproses untuk mengetahui persentase kelembaban di dalam tanah.

b. Arduino uno berfungsi sebagai penerima data yang dikirim dari sensor kelembaban tanah kemudian menginstruksikan.

c. Pompa air adalah alat yang digunakan untuk memindahkan air dari suatu tempat ke tempat lain melalui saluran (pipa) dengan menggunakan tenaga listrik untuk mendorong air yang di pindahkan secara terus menerus.

d. PWM digunakan untuk mengatur cepat atau lambatnya pompa yang digunakan.

2. Perancangan Perangkat Lunak (Sofware)

Sistem Instrumentasi yang berbasis mikrokontroler memerlukan urutan instruksi yang disebut program.Program system alat penyiraman tanaman ini ditulis dalam bahasa pemrograman IDE Arduino. Perancangan perangkat lunak dimulai dari perancangan diagram alir. Berdasarkan prinsip kerja sistem yang direncanakan maka diagram alir program dapat ditampilkan seperti pada diagram 5.

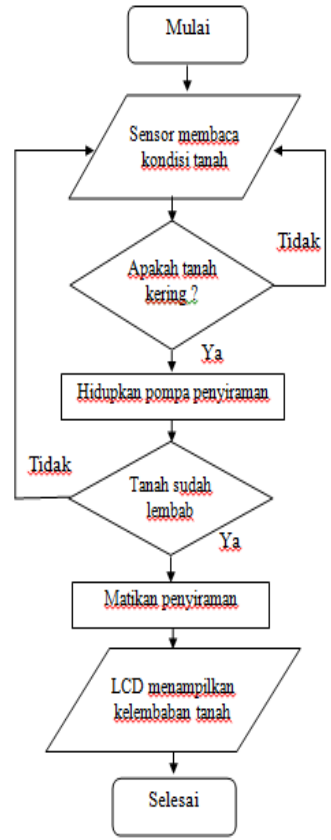

Gambar 5. Diagram alir proses pengukuran kelembaban tanah 
Saat sistem dijalankan, sensor kelembaban tanah akan mendeteksi kondisi tanah, jika kondisi tanah kering kelembabannya maka pompa air hidup untuk menyiram tanaman. Jika sensor kelembaban tanah mendeteksi tanah sudah lembab maka pompa air akan mati, dan Output Nilai kelembaban tanah akan ditampilkan pada LCD.

3. Metode Logika Fuzzy

Pada penelitian ini menggunakan metode logika fuzzy Sugeno, output yang digunakan berupa konstanta atau persamaan linier.

a. Fuzzifikasi

Sensor kelembaban tanah dibaca oleh mikrokontroler, lalu dibentuk pernyataan linguistiknya.

Tabel 1. Variabel Linguistic Kelembaban tanah

\begin{tabular}{|c|c|c|}
\hline Kelembaban tanah (\%) & Variabel linguistic & Keterangan \\
\hline $0-25$ & Kering & $\mathrm{Kr}$ \\
\hline $15-55$ & Lembab & $\mathrm{Lm}$ \\
\hline$\geq 45$ & Basah & $\mathrm{Bs}$ \\
\hline
\end{tabular}

Berdasarkan Tabel diatas, maka grafik yang menunjukan hubungan dari ketiga variabel linguistic dapat dilihat pada Gambar 6.

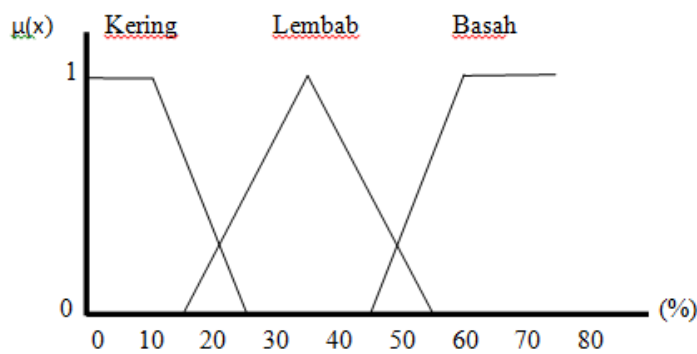

Gambar 6. Fungsi keanggotaan Variabel Sensor

b. Mesin Inferensi

Pada tahap ini pengambilan keputusan dilakukan berdasarkan logika-logika yang telah dibangun sehingga menghasilkan suatu keputusan berupa perintah atau tindakan sesuai pengendalian yang diinginkan.

Tabel 2. Aturan Dasar

\begin{tabular}{|c|c|c|c|}
\hline $\begin{array}{c}\text { Input 1 } \\
\text { Sensor Kelembaban 1 }\end{array}$ & $\begin{array}{c}\text { Input 2 } \\
\text { Sensor Kelembaban 2 }\end{array}$ & $\begin{array}{c}\text { Output 1 } \\
\text { Debit air }\end{array}$ & $\begin{array}{c}\text { Output 2 } \\
\text { PWM }\end{array}$ \\
\hline Kering & Kering & Banyak & Cepat \\
\hline Kering & Lembab & Banyak & Cepat \\
\hline Kering & Basah & Banyak & Cepat \\
\hline Lembab & Kering & Banyak & Cepat \\
\hline Lembab & Lembab & Cukup & Sedang \\
\hline Lembab & Basah & 0 & Mati \\
\hline Basah & Kering & 0 & Mati \\
\hline Basah & Lembab & 0 & Mati \\
\hline Basah & Basah & 0 & Mati \\
\hline
\end{tabular}

c. Defuzzifikasi

Dipilih 3 buah nilai linguistik untuk menentukan kondisi dari lama waktu penyiraman yang direpresentasikan dalam bentuk fungsi keanggotaan singleton sebagaimana terlihat pada gambar 7 .

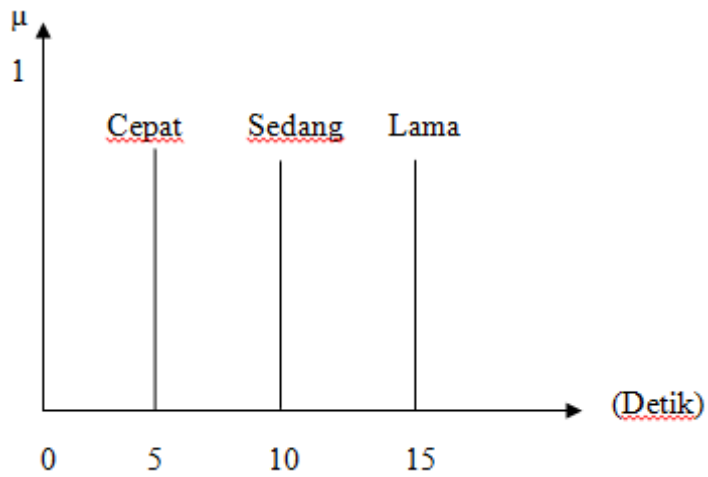

Gambar 7. Diagram Singleton lama penyiraman

Dimana :

$\begin{array}{ll}\text { - } \text { Cepat } & =5 \text { Detik } \\ \text { - Sedang } & =10 \text { Detik } \\ \text { - Lama } & =15 \text { Detik }\end{array}$

Dan dipilih 3 buah nilai linguistik untuk menentukan kondisi dari banyak debit air yang direpresentasikan dalam bentuk fungsi keanggotaan singleton sebagaimana terlihat pada gambar 8 .

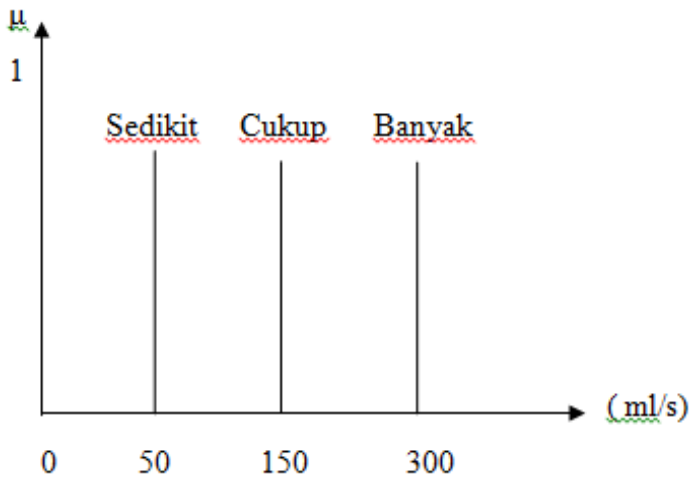

Gambar 8. Diagram Singleton debit air yang keluar

Dimana :

$\begin{array}{ll}\text { - } \text { Sedikit } & =50 \mathrm{ml} / \mathrm{s} \\ \text { - } \text { Cukup } & =150 \mathrm{ml} / \mathrm{s} \\ \text { - } \text { Banyak } & =300 \mathrm{ml} / \mathrm{s}\end{array}$

\section{Pembahasan}

\section{A. Hasil pengujian}

Pembuatan dari sistem Penyiraman tanaman Otomatis berbais sensor kelembaban tanah menggunakan logika fuzzy, dalam pengujiannya terbagi menjadi dua yaitu pengujian fungsional atau uji tiap bagian pada alat yang digunakan, dan pengujian kinerja atau unjuk kerja penyiraman tanaman menggunakan logika fuzzy.

1. Pengujian Hardware

Pengujian Hardware merupakan pengujian tiap bagian atau blok pada alat yang digunakan. Pengujian fungsional bertujuan untuk mengetahui alat dan aplikasi 
yang telah dibuat apakah bekerja sesuai dengan yang diinginkan.

a. Hasil Pengujian Power Supply dan Step Down

Tabel 3. Hasil Pengujian Power Supply dan Step down

\begin{tabular}{|c|c|c|c|c|}
\hline Catu daya & $\begin{array}{c}\text { Pengujian } \\
\text { ke- }\end{array}$ & $\begin{array}{c}\text { V-out } \\
\text { (volt) }\end{array}$ & $\begin{array}{c}\text { V-out } \\
\text { terbaca } \\
\text { (volt) }\end{array}$ & $\begin{array}{c}\text { Selisih } \\
\text { tegangan } \\
\text { (volt) }\end{array}$ \\
\hline $\begin{array}{c}\text { Power supply 12V/5A } \\
\text { (Adaptor) }\end{array}$ & 1 & 12 & 12.1 & 0.1 \\
\cline { 2 - 5 } & 2 & 12 & 12.1 & 0.1 \\
\hline $\begin{array}{c}\text { Step down 5V/3A } \\
\text { (LM2596) }\end{array}$ & 1 & 5 & 5.2 & 0.2 \\
\cline { 2 - 5 } & 2 & 5 & 5.2 & 0.2 \\
\hline
\end{tabular}

Data Tabel 3 merupakan hasil dari pengujian power supply dan step down untuk mengetahui outputnya. Output dari power supply digunakan sebagai input pompa air 12 volt sedangkan output dari step down digunakan sebagai input mikrokontroller. Pengujian power supply (Adaptor) dan step down (LM2596) dapat di lihat pada gambar berikut.

b. Hasil Pengujian Kelembaban Tanah

Tabel 4. Hasil Pengujian Kelembaban Tanah

\begin{tabular}{|c|c|c|c|}
\hline \multirow{2}{*}{ Pengujian } & $\begin{array}{c}\text { Volume } \\
\text { Air (ml) }\end{array}$ & Nilai Sensor & $\begin{array}{c}\text { Kelelembaban } \\
\text { Tanah (\%) }\end{array}$ \\
\hline \multirow{4}{*}{$\begin{array}{c}\text { SELEMBOR } \\
\text { SEANAN } \\
\text { TANAH }\end{array}$} & 80 & 772.3 & 24.5 \\
\cline { 2 - 4 } & 170 & 668 & 34.7 \\
\cline { 2 - 4 } & 250 & 543.2 & 46.9 \\
\cline { 2 - 4 } & 306 & 478.76 & 53.2 \\
\cline { 2 - 4 } & 320 & 367.25 & 59.7 \\
\cline { 2 - 4 } & 392 & 293.6 & 71.3 \\
\hline
\end{tabular}

Data Tabel 4.2 merupakan hasil pengujian sensor kelembaban tanah, untuk mendapatkan nilai persentase kelembaban tanah dalam pengujian sensor kelembaban tanah adalah sebagai berikut:

Persentase kelemababan tanah pada saat volume air 80 ml dengan nilai sensor adalah 772.3, nilai 1023 adalah nilai ADC dari sensor kelembaban tanah yang menggunakan 10 bit.

$\begin{array}{ll}\text { KelembabanTanah }(\%) & =\frac{(102 a-\text { Nilai Sensor })}{(10.2 a)} \\ \text { KelembabanTanah }(\%) & =\frac{(102 a-772.9)}{10.2 a} \\ \text { Kelembaban Tanah }(\%) & =24,5\end{array}$

Pengujian kelembaban tanah dapat dilihat pada gambar berikut.

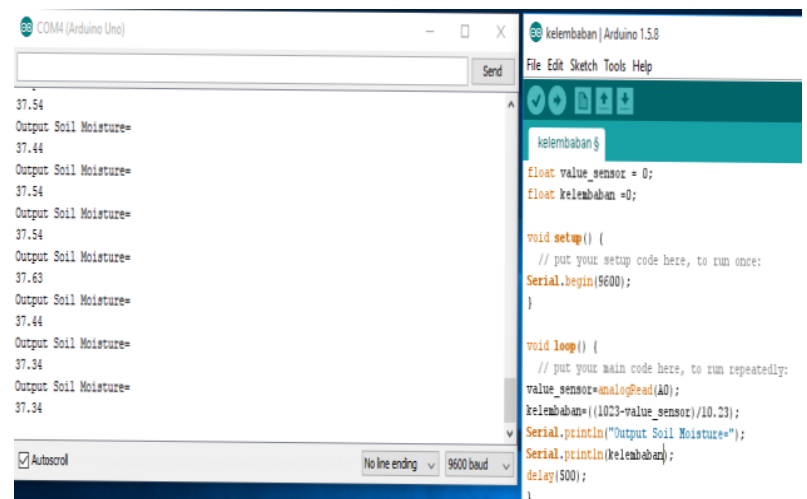

Gambar 11. Pengujian Program Sensor Kelembaban Tanah

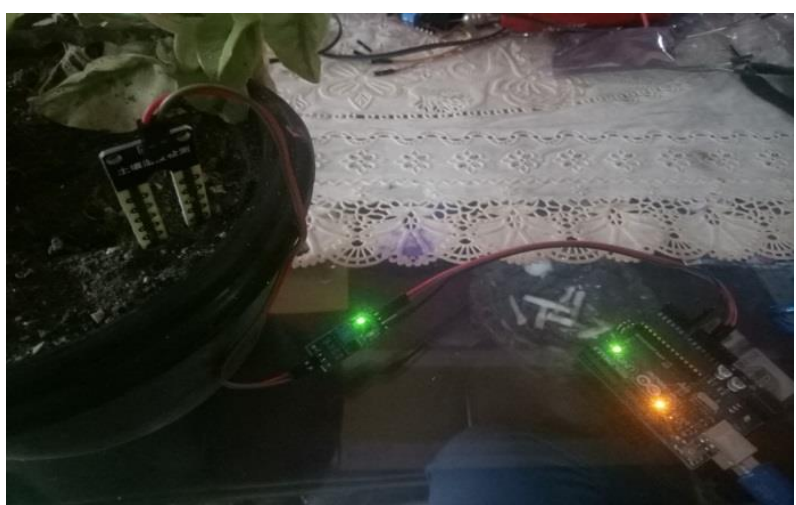

Gambar 12. Pengujian Sensor Kelembaban Tanah

c. Hasil Pengujian Pompa Air

Tabel 5. Hasil Pengujian Pompa Air

\begin{tabular}{|c|c|c|}
\hline PWM & Tegangan Driver (Volt) & Duty Cycle Driver \\
\hline 255 & 11.1 & $100 \%$ \\
\hline 189 & 8.1 & $75 \%$ \\
\hline 126 & 5.5 & $50 \%$ \\
\hline 63 & 2.5 & $25 \%$ \\
\hline 0 & 0 & $0 \%$ \\
\hline
\end{tabular}

Tabel 5 merupakan hasil pengujianpompaair dan dibantu L298 untuk mengatur cepat lamabatnya PWM pompaair. Pengujian pompa dapat dilihat pada gambar berikut.

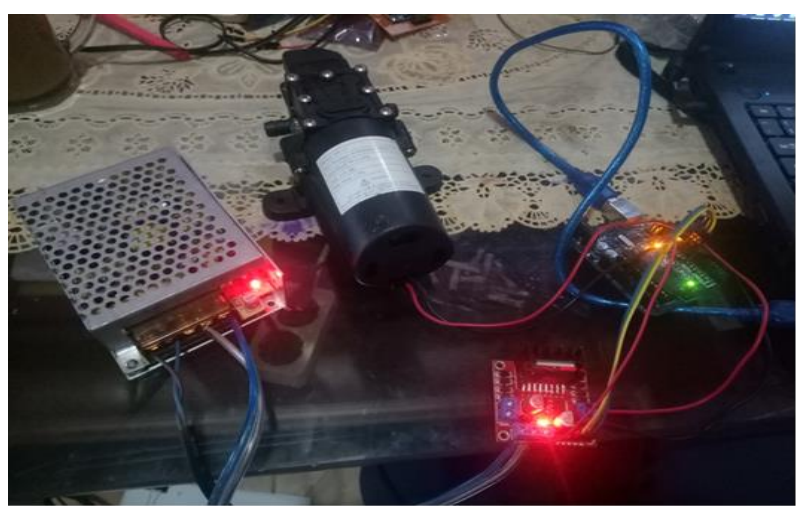

Gambar 13. Pengujian Pompa Air 


\section{d. Hasil Pengujian LCD}

Rangkaian LCD dirancang bersama dengan Arduino Uno.Pengujian yang dilakukan untuk melihat apakah program yang ditanam dalam Arduino Uno dapat bekerja sesuai dengan yang diinginkan.Program ini di tulis dengan Arduino IDE.Hasil Pengujian menunjukkan bahwa Arduino Uno dapat menuliskan data ke LCD.Pengujian LCD dapat dilihat pada gambar berikut.

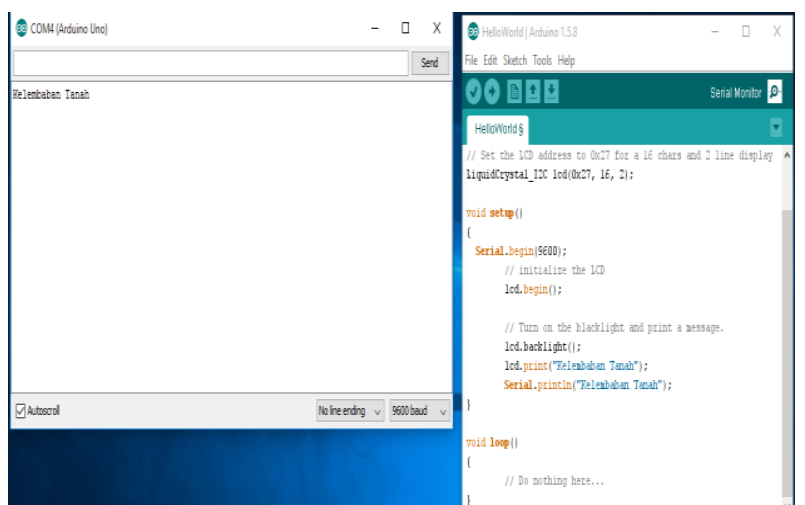

Gambar 14. Pengujian Program LCD

\section{Pengujian Software}

Tahapan pengujian software terdiri dari perancangan fuzzy logic controller yang menggunakan software Arduino. Digunakan Monitor software Arduino untuk menampilkan hasil pembacaan sistem. Dari data tersebut akan diamati respon dari kontrol yang digunakan. Sistem dikendalikan menggunakan metode Fuzzy Logic Controller.Pada percobaan ini, input yang digunakan berjumlah 2 buah sensor yaitu sensor kelembaban tanah. Nilai tersebut akan berpengaruh pada kecepatan motor DC yang pada percobaan ini diatur melalui penetapan nilai PWM. Terdapat 3 buah nilai PWM yaitu 0 untuk mengatur pompa mati, 150 untuk mengatur kecepatan pompa sedang dan 250 untuk mengatur kecepatan pompa cepat.

3. Pengujian Sistem (Keseluruhan kinerja Alat)

Pengujian kinerja alat penyiraman tanaman otomatis dengan logika fuzzy bertujuan untuk mengetahui cara kerja dari sistem logika fuzzy pada penyiraman air. Unjuk kerja tersebut dimodelkan sebagai ketepatan waktu penyiraman atau output sistem logika fuzzy pada Arduino.

4. Pembahasan

Dalam pengoperasiannya logika sudah berjalan dengan baik dimana, input kelembaban tanah difuzyfikasikan menjadi masing-masing 3 buah domain, kemudian data diolah oleh mikrokontroler dengan menggunakan fuzzy inferen sistem. Berdasarkan rule yang berlaku maka diperoleh output motor dengan dengan menggunakan max-min composition. Bahwa fuzzy sudah di terapkan dengan baik, hal ini terlihat dari hasil pengujian dimana saat kelembaban 1 bernilai $51,64 \%$ dan kelembaban 2 bernilai $53,76 \%$ dimana kondisi tanah tersebut basah,maka tanaman tersebut tidak akan disiram. Hal ini di dapatkan dari pengetahuan yang diterapkan kedalam mikrokontroler, kemudian ketika kelembaban tanah 1 bernilai $14,08 \%$ dan kelembaban tanah 2 bernilai 0,24\% dimana kondisi tanah kering, maka waktu penyiraman tanaman tersebut berdurasi "lama". Dimana kondisi "Lama" ini telah diatur sesuai dengan rule yang ditanamkan pada mikrikontroller.

\section{Kesimpulan}

Berdasarkan hasil pengujian dari alat penyiram tanaman otomatis dengan logika fuzzy maka dapat diambil kesimpulan sebagai berikut:

1. Secara keseluruhan alat yang telah dibuat untuk mengukur nilai kelembaban tanah dapat berfungsi dengan baik. Hasil ini dilakukan berdaasarkan 20 kali pengujiaan diperoleh hasil pengujian dimana saat tanah kering bernilai 3,21\% maka waktu penyiraman berdurasi lama, tanaman tersebut akan disiram, pompa akan menyala dan menyiram sesuai dengan lama waktu penyiraman yang telah di program, dan jika tanah tersebut basah bernilai 50,19 \% maka tanaman tersebut tidak akan disiram dan pompa tidak akan hidup. Dimana kondisi ini telah diatur sesuai dengan rule yang telah ditetapkan.

2. Sistem dapat menyiram air kepada tanaman apabila nilai kelembaban tanah dibawah $45 \%$ dan sitem tidak dapat menyiram air apabila nilai kelembaban tanah diatas $45 \%$.

3. Unjuk kerja dari sistem penyiraman tanaman otomatis menggunakan fuzzy logic control, berdasarkan hasil pengujian yang telah dilaksanakan dapat berfungsi dengan baik dari segi sistem cerdas yang berbasis logika fuzzy maupun Sistem penyiraman. Sensor kelembaban tanah bekerja dengan baik dan benar.

Saran

Setelah melakukan pengujian terhadap kinerja dari alat penyiram tanaman otomatis dengan logika fuzzy, ada beberapa saran yang di berikan dari penulis untuk kesempurnaan alat ini, yaitu:

1. Menambah membership function sehinggga memungkinkan untuk menghasilkan output keadaan yang lebih mendetail.

2. Menggunakan sensor yang mempunyai sensitifitas lebih baik lagi.

3. Membuat alat dengan skala yang lebih besar sehingga dapat diterapkan pada perkebunan.

\section{Daftar Pustaka}

Sintia, M., 2008, kebonkembang.com, http://www.kebonkembang.com/panduan-dan-tiprubrik-35/dasar pengetahuan-kebutuhan-air-padatanaman.htm.

Pranata, T., Irawan, B., \& Ilhamsyah.(2015). Penerapan Logika Fuzzy Pada Sistem Penyiraman Tanaman Otomatis Berbasis Mikrokontroler.Coding Jurnal Komputer Dan Aplikasi Untan, 03(2), 1-12. 
Kurniawan, B. A. 2015.Alat Penyiraman Tanaman Otomatis dengan Logika Fuzzy Berbasis ATMega16 The Automatic Plant Sprinkler With a Fuzzy's Logic Based on ATMega 16 Oleh: Bayu Aji Kurniawan (12507134003),. 16(12507134003), $1-8$.

BATARA NAIBAHO, I. 2017. Penyiraman Otomatis Pada Tanaman Berbasis Arduino Menggunakan Sensor Kelembapan Tanah.

Gunawan, \& Sari, M. 2018. Rancang Bangun Alat Penyiram Tanaman Otomatis Menggunakan Sensor Kelembaban Tanah. Journal of Electrical Technology, 3, 1.

Pid, C., Informatika, J. T., Teknik, F., \& Oleo, U. H. (2016). Implementasi robot.2(1), 111-124.

Palupi, D. N. 2018. Digital Digital Repository Repository Universitas Universitas Jember Jember Digital Digital Repository Repository Universitas Universitas Jember.

Detector, A. M. 2017. Rancang Bangun Deteksi Jalur Pipa Terpendam Menggunakan Mobile Robot dengan Metal. 6(1).

Tullah, R., Setyawan, A. H., \& Tanah, B. P. 2019. Sistem Penyiraman Tanaman Otomatis Berbasis Mikrokontroler Arduino Uno Pada Toko Tanaman Hias Yopi. 9(1).

Masturi et al., 2017. Prototype Of Automation Of Water Content Based On Fuzzy Logic. Universitas Telkom. 